\title{
Elhunyt dr. Molnár László vegyész, fejlesztőmérnök (1944-2020)
}

A haditechnikai tudományterület szakmai közösségét és lapunk munkatársait egyaránt váratlanul érte a hír, hogy dr. Molnár László professzor 2020. május 17-én, életének 77 . évében elhunyt.

Dr. Molnár László a hadtudomány kandidátusa, a Haditechnikai Intézet fejlesztőmérnöke, a Mechanikai Művek vezérigazgatóhelyettese, vegyészként évtizedeken keresztül aktív részese volt a hazai lőszer- és robbanóanyag gyártásnak, szakértő munkája számos hadiipari fejlesztéshez kapcsolja nevét. Molnár László, 1944. április 10-én született Budapesten. 1963-ban felvételt nyert az Eötvös Loránd Tudományegyetem Természettudományi Karának vegyész szakára, ahol 1968-ban jeles eredménynyel megvédte diplomáját. Diplomamunkájának témája a „Gyutacsgyártás iniciáló anyagaként felhasználásra kerülő mikrokristályos ólom-azid és trizinát előálítása és vizsgálata" volt. 1968 júliusától 1975 áprilisáig a Magyar Néphadsereg Haditechnikai Intézetének vegyi osztályán, tudományos előadó beosztásban dolgozott. Feladatai közé tartozott a TNT robbanóanyag olajosodásának vizsgálata, a termit anyagok gyártásbevezetése, a szilárd rakéta-hajtóanyagok égési tulajdonságainak kutatása, illetve a jégeső-elhárító rakéta hajtóanyagának és robbanó töltetének kidolgozása. Részt vett a 120 mm-es aknavető lőszerének rakétapóthajtás-, illetve a 82 mm-es BEKM (Berkesi - Elek - Kocsis - Molnár konstruktőr-mérnökök) típusú repesz-kumulatív aknagránát fejlesztésében is. 1972-ben az Eötvös Loránd Tudományegyetemen megvédte doktori disszertációját. Értekezése témája a „Keverék típusú rakéta-hajtóanyagok égési sebességének vizsgálata" volt. 1975 és 1977 között a Vegyi- és Robbanóanyag Ipari Felügyeletnél dolgozott osztályvezetői beosztásban, ahol a honvédségi igényeknek megfelelő kumulatív robbantóeszközök és jégeső-elhárító rakéták fejlesztési munkálatait irányította. Dr. Molnár László 1977 augusztusától 2004 júliusáig, nyugdíjazásáig a Mechanikai Művek (MM) hadiipari komplexumban dolgozott, először a Speciális (Hadiipari) Gyáregység helyettes vezetőjeként, később vezetőjeként, majd a jogutód MM Speciális Divízió igazgatójaként, végül az MM Speciális Részvénytársaság vezérigazgatójaként. Feladata a honvédségi igényeknek megfelelő hadiipari termelés és a fejlesztések irányítása, továbbá (részben) a bányászati célú robbantóeszközök gyártásának és fejlesztésének irányítása volt. Az MM hadiipari tevékenysége az 57-152 mm ürméretű tüzérségi lőszerek, valamint a 81-120 $\mathrm{mm}$ ürméretű aknalőszerek véglegesre szerelése, robbanóanyaggal történő töltése; műszaki harcanyagok - robbanóanyag préstestek, gyalogság- és harckocsi elleni aknák
- gyártása volt. Emellett kézigránátok, puskagránátok gyártásával is foglalkoztak, fejlesztéseik egyebek mellett reaktív páncél tégláira, illetve implóziós és aeroszol robbanóanyagokra irányult. Dr. Molnár László tudományos területen a brizáns robbanóanyagok detonációjának elméletével, ezen belül az irányított detonáció vizsgálatával foglalkozott. A Zrínyi Miklós Nemzetvédelmi Egyetem speciális képzésén 1991-ben szerzett oklevelet. 1992-ben a Magyar Tudományos Akadémia Hadtudományi Szakbizottsága előtt megvédte az „Implóziós robbantás" tárgyú értekezését, és elnyerte a hadtudomány (haditechnika) kandidátusi fokozatát. 1982 és 1990 között a Kölcsönös Gazdasági Segítség Tanácsa Hadiipari Állandó Bizottság tüzérségi lőszergyártási technológiákat kidolgozó magyarországi munkacsoportjának vezetője volt. 1975 és 2007 között az Eötvös Loránd Tudományegyetemen, a Miskolci Nehézipari Egyetemen és a Zrínyi Miklós Nemzetvédelmi Egyetemen óraadó tanárként speciális robbantási ismereteket oktatott. A Nemzeti Közszolgálati Egyetem Hadtudományi Doktori Iskolájának oktatója, illetve a Magyar Szabványügyi Testület Katonai Szabványosítási Munkabizottság elnöke volt.

Közel ötven tudományos publikációval és öt szabadalommal rendelkezett. Kitüntetései közül a legrangosabb a Haza Szolgálatáért Érdemérem és az International Award DETOPRIM elismerése, illetve a Weindl Gáspár Díj. Dr. Molnár László a Magyar Hadtudományi Társaság Műszaki Szakosztály és a Magyar Katonai Logisztikai Egyesület, illetve a Magyar Robbantástechnikai Egyesület örökös tagja volt.

Professzor úr több alkalommal publikált a Haditechnika folyóiratban, legutóbb, idei 1. számunkban „Eljárás az aeroszol robbanó harcanyagok/harci részek hatásjellemzőinek meghatározására - hazai kutatási eredmények" címmel, azt megelőzően 2019/1. számunkban a „Gyors működésű gyutacs-detonátor felépítésének modellezése” címmel jelent meg tanulmánya. Molnár Professzor Úr minden szakcikke lapunk vezető anyaga volt. Azon szerencsés munkatársainak mondhatjuk magunkat, akik személyesen ismerhették Öt, hiszen rendszeresen bejárt hozzánk a Haditechnika lap szerkesztőségébe. Megtisztelt minket szakmai beszámolóival és eleganciájával, hiszen régi vágású úriemberként nyakkendőt kötött és sötét öltönyt viselt. Cikkeit is olyan precíz módon öntötte formába, ami minden szerzőnk számára példa lehet.

Szerkesztőségünkkel betegsége idején is tartotta a kapcsolatot, lektori feladatot vállalt és új cikkterven dolgozott. Elhunytával a hazai haditechnika „Nagy Generációjának” egyik kiemelkedő személyisége távozott. 